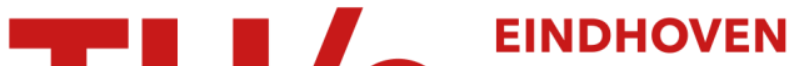 UNIVERSITY OF TECHNOLOGY
}

\section{Location type choice for face-to-face interactions in business centers}

Citation for published version (APA):

Weijs - Perrée, M., Appel - Meulenbroek, H. A. J. A., \& Arentze, T. A. (2018). Location type choice for face-toface interactions in business centers. Abstract from 25th Annual European Real Estate Society Conference (ERES 2018), Reading, United Kingdom.

Document status and date:

Published: 01/01/2018

\section{Document Version:}

Publisher's PDF, also known as Version of Record (includes final page, issue and volume numbers)

\section{Please check the document version of this publication:}

- A submitted manuscript is the version of the article upon submission and before peer-review. There can be important differences between the submitted version and the official published version of record. People interested in the research are advised to contact the author for the final version of the publication, or visit the $\mathrm{DOI}$ to the publisher's website.

- The final author version and the galley proof are versions of the publication after peer review.

- The final published version features the final layout of the paper including the volume, issue and page numbers.

Link to publication

\section{General rights}

Copyright and moral rights for the publications made accessible in the public portal are retained by the authors and/or other copyright owners and it is a condition of accessing publications that users recognise and abide by the legal requirements associated with these rights.

- Users may download and print one copy of any publication from the public portal for the purpose of private study or research.

- You may not further distribute the material or use it for any profit-making activity or commercial gain

- You may freely distribute the URL identifying the publication in the public portal.

If the publication is distributed under the terms of Article 25fa of the Dutch Copyright Act, indicated by the "Taverne" license above, please follow below link for the End User Agreement:

www.tue.nl/taverne

Take down policy

If you believe that this document breaches copyright please contact us at:

openaccess@tue.nl

providing details and we will investigate your claim. 


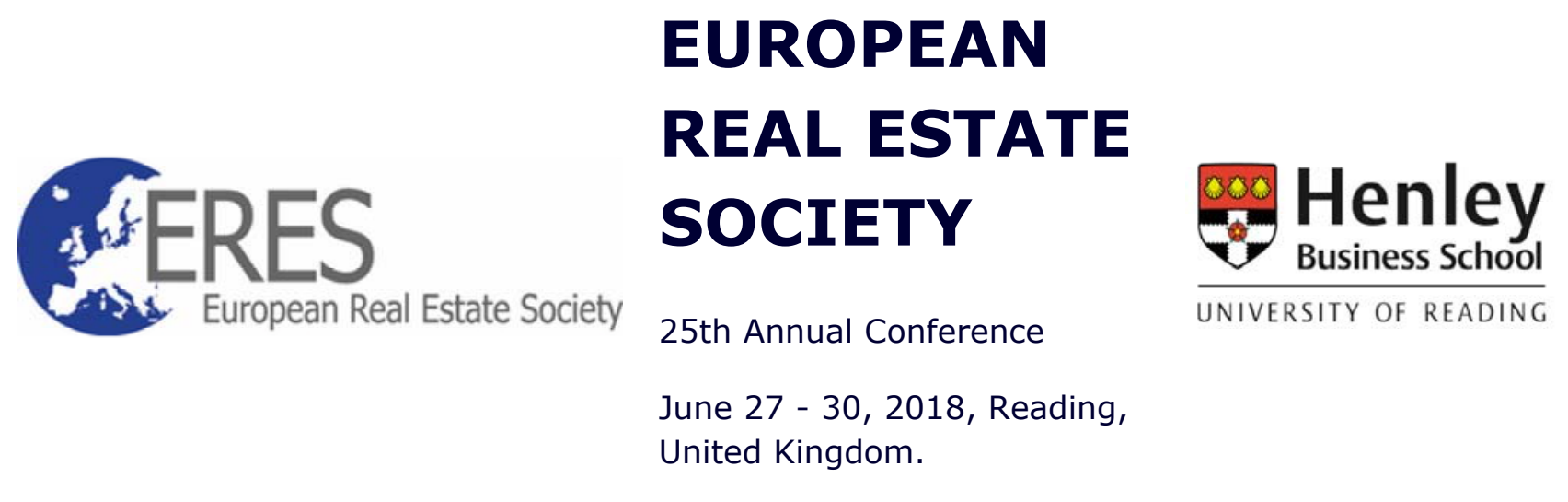

\section{Abstracts}

You have requested the abstract for paper number 335:

Minou Weijs-Perrée, Eindhoven University of Technology, Eindhoven, Netherlands, Rianne Appel-Meulenbroek, Theo Arentze, Eindhoven University of Technology, Eindhoven, The Netherlands

Location type choice for face-to-face interactions in business centers (assigned to theme $\underline{\mathbf{Z D}-1}$ )

As business centers offer shared workspaces and facilities to multiple organizations, it is expected that these organizations interact more frequently with each other. More empirical research is needed on where these interactions take place in business centers and how this behavior is influenced. Therefore, the aim of this study is to analyze the location choice for face-to-face interactions of business center users. Data collected by means of a questionnaire and an Experience Sampling Method (ESM), was analyzed using a Mixed Multinomial Logit Model (MMNB Results showed that interorganizational interactions take place less frequently at workspaces or formal meeting spaces and more frequently at shared spaces such as the coffee corner, café/restaurant/canteen or at other informal spaces. These interactions are also more likely to be influenced by features of the physical work environment, as these interactions were found to be mainly coincidental compared to the intra-organizational interactions. These findings could help office designers with regard to stimulating faceto-face interactions among organizations in business centers. 